\title{
CUSHING REFLEX: A SIGN OF VESSEL PERFORATION DURING MECHANICAL THROMBECTOMY PERFORMED UNDER GENERAL ANESTHESIA
}

\author{
Bedih BALKAN*, Abdülcelil GEZMiş ${ }^{*}$, Ahmet Tolga EROL*, Batuhan KARA**, \\ Hatem Hakan SELÇUK**, Abdulkadir YEKTAS ${ }^{* * *}$ \\ *TC. Medical Sciences University Bakırköy Dr. Sadi Konuk Training and Research Hospital, \\ Department of Anesthesiology and Reanimation, ISTANBUL, TURKEY \\ ** TC. Medical Sciences University Bakırköy Dr. Sadi Konuk Training and Research Hospital, \\ Department of Radiology, ISTANBUL, TURKEY \\ *** TC. Medical Sciences University Diyarbakır Gazi Yaşargil Training and Research Hospital, \\ Department of Anesthesiology and Reanimation, DIYARBAKIR, TURKEY
}

\begin{abstract}
We aimed to present the assessment of the Cushing reflex caused by intracranial haemorrhagia developing during mechanical thrombectomy in a case presenting with acute ischemic stroke. A 59-year old male patient was scanned by CT angio due to speaking disorder and right lateral weakness developing 5 hours earlier. Acute infarction was observed in the left MCA irrigation area with M1 segment occlusion observed in the left MCA. The decision was made to treat the patient with mechanical thrombectomy and he was transferred to the interventional neuroradiology unit. Under general anesthesia during navigation of the thromboaspiration catheter to the clot localization as the procedure was technically advancing routinely, with sudden development of bradycardia and hypertension the anesthesiology team was warned and $1 \mathrm{mg}$ IV atropine was administered for bradycardia. Acute infarction has to be removed because it is understood as mechanical thrombectomy has been performed to a patient with an infarction. Simultaneously contrast material injection through the guide catheter showed the MCA M1 segment had ruptured and extravasation had developed. As conclusion, anesthesia and operation team must be alert for vessel perforation when Cushing triad develops during navigation of the thromboaspiration catheter.
\end{abstract}

Keywords: Cushing reflex, acute stroke, mechanical thrombectomy, general anesthesia, vessel perforation.

\section{CUSHING REFLEKSI: GENEL ANESTEZI ALTINDA YAPILAN MEKANIK TROMBEKTOMİ ESNASINDA DAMAR PERFORASYONUN BIR IŞ̧ARETI}

\section{ÖZET}

Akut iskemik stroklu olguda mekanik trombektomi esnasında gelișen intrakranial hemorajiye nedenli Cushing refleksinin değerlendirilmesi amaçlandı. Beş saat önce gelişen sağ yan güçsüzlüğü ve konuşma bozukluğu nedenli BT-anjiyo çekilen 59 yaşında erkek hastada sol MCA'da M1 segment oklüzyonu görüldü. Tedavi kararı hastaya mekanik trombektomi uygulanması oldu ve hasta girişimsel nöroradiyoloji ünitesine sevk edildi. Genel anestezi altında prosedür olarak pıhtı lokalizasyonuna tromboaspirasyon kateterinin yerleştirilmesi esnasında rutin bir şekilde teknik olarak ilerlendi, Ansızın bradikardi ve hipertansiyon gelişti ve anestezi ekibi $1 \mathrm{mg}$ atropin uyguladı. Bradikardi ve hipertansiyonun infarktüslü bir hastada yapılan mekanik trombektomiye bağlı olduğu düşünüldüğü için akut infarktüsten uzaklaşıldı. Eş zamanlı kateterden kontrast madde verilerek MCA M1 segmentinde rüptür ve kontrast maddenin dişarı sızması görüldü. Sonuç olarak, anestezi ve operasyon ekibi tromboaspirasyon kateteri yerleștirilmesi esnasında Cushing refleksi geliştiği zaman damar perforasyonu açısından uyanık olmalıdır.

Anahtar Sözcükler Cushing refleksi, akut strok, mekanik trombektomi, genel anestezi, damar perforasyonu.

\footnotetext{
Corresponding author: Abdulkadir Yektas, Assoc. Prof. MD. TC. Medical Sciences University Diyarbakır Gazi Yaşargil Training and Research Hospital, Department of Anesthesiology and Reanimation, Diyarbakır, Turkey

Phone: +900412 $2580060 \quad$ E-mail: akyektas722000@yahoo.co.uk

Received: 06.05.2018 Accepted: 29.05.2018

This article should be cited as following: Balkan B, Gezmiş A, Erol A.T, Kara B, Selçuk H. H, Yektaş A. Cushing reflex: a sign of vessel perforation during mechanical thrombectomy performed under general anesthesia. Turkish Journal of Cerebrovascular Diseases 2018; 24 (2): 82-86. doi:10.5505/tbdhd.2018.50251
} 


\section{INTRODUCTION}

Due to technologies developing in the last two decades, endovascular methods have gained importance for the treatment of many cerebrovascular diseases. Generally complications encountered in endovascular treatments may be classified as hemorrhagic and thromboembolic complications. Of these, the hemorrhagic complications have higher mortality and morbidity. Hockel K. et al. (1) were doing animal study, demostrated that there was a significantly lower mortality rate in the SAH_V1 receptor antagonist group (2 of 10 [20\%]) compared with the SAH_vehicle group (5 of 10 [50\%]) during the 7day posthemorrhagic observation period $(\mathrm{P}<0.05)$. Extravasation during the procedure always be identified angiographically, still late awareness of hemorrhagic complications and as a result negative effects on survival. Intracranial pressure (ICP) is the pressure within the cranium. ICP rise compresses brain vessels and reduces cerebral blood delivery (2). In situations where the intracranial pressure (ICP) suddenly increases, hypertension, bradycardia and respiratory irregularity may be observed (2). Called the Cushing reflex after the researcher who first observed them, acknowledging these findings and informing the operation team positively changes the progress of hemorrhagic complications encountered during neuroendovascular treatments. One still unresolved question is whether the Cushing response is a non-synaptic acute brainstem ischemic mechanism or part of a larger physiological reflex for arterial blood pressure control and homeostasis regulation (2). In this case report, we aim to discuss a case with arterial rupture during mechanical thrombectomy for acute stroke which was not noticed by the operation team during the procedure. However, after the Cushing reflex was identified by the anesthesia team, the arterial rupture was confirmed angiographically, necessary treatments were applied and the case survived.

\section{CASE}

A 59-year old male case applying to the emergency service with aphasia and right-side weakness was determined to have by-pass, aorta valve replacement and to use coumadine on assessment. The patient had blood pressure
$165 / 95 \mathrm{mmHg}$, pulse 120 beats/min, fever $36.2^{\circ} \mathrm{C}$, and respiratory count $18 / \mathrm{min}$.

Neurological examination of the patient found open consciousness, with no cooperation, no response to orders, no verbal output and aphasia. There were no findings of nuchal stiffness and meningeal irritation. Pupils were isochoric and had bilateral light response. There was no nystagmus. Right nazo labial sulcus (NLS) was faint, uvula and gag reflex could not be assessed. Paresia tests found right upper and lower extremities could not overcome gravity, with muscle power of the right upper and lower $2 / 5$, tonus was normal, and senses could not be evaluated. The National Institute of Health stroke scale (NIHSS) was calculated as 16.

Laboratory investigations were AST: $44 \mathrm{U} / \mathrm{L}$ (0-35), ALT: 164(0-45) U/L, Glucose 148 (60-100) $\mathrm{mg} \mathrm{dL}-1$, creatinine $1.49(0,5-1,4) \mathrm{mg} / \mathrm{dL}$, Urea $35(5,0-21) \mathrm{mg} / \mathrm{dL}$. In venous blood gases $\mathrm{pH}: 7.40$, P02: 41.6, mmHg, PCO2: 44.9, mmHg, SPO2; 65. Lactate was $2.13 \mathrm{mmol} / \mathrm{L}$. On coagulometry: İNR ;3.34 s N (0.8 - 1.2 s), PtZ; 37.2 s N (10-15) s, aPTT $44 \mathrm{~s} \mathrm{~N}(23.2-35.2 \mathrm{sn})$.

On non-contrast computed cerebral tomography (CT) acute intracranial hemorrhage was not identified (Figure I).

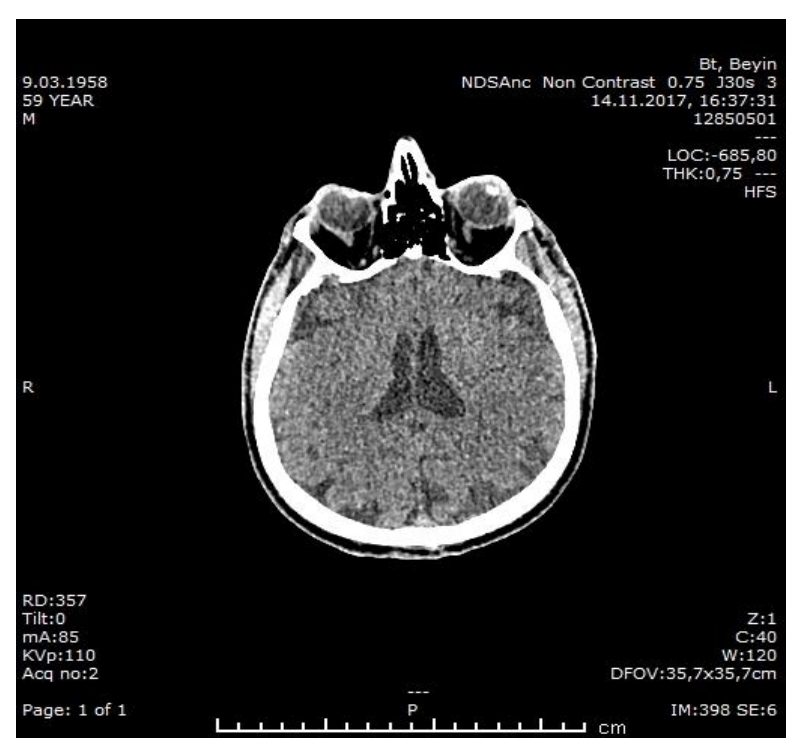

Figure I. Non-contrast computed cerebral tomography (CT).

CT-angiography showed M1 segment occlusion in the left middle cerebral artery (MCA). Patient's ASPECT score was 8 . As the INR value was 
high, intravenous thrombolysis treatment was contraindicated so the decision was made to treat the case with mechanical thrombectomy after consultation with the neuroradiology team.

The patient was taken to anesthesia with American Society of Anesthesiologists (ASA) Emergency. When the patient was placed on the operating table for intervention veneous route was already inserted. After standard monitorization (heart rate (HR), blood pressure (BP), oxygen saturation (Sp02) 0.9\% saline infusion was begun through the venous access. Before induction blood pressure was $180 / 100 \mathrm{mmHg}$, heart rate was 124 beats/min and SpO2 was 95 and the patient was given $3 \mathrm{mg} / \mathrm{ml}$ dose of IV midazolam (Dormicum® Roche-Germany). After administering $2 \mu \mathrm{gr} / \mathrm{kg}$ fentanyl citrate (Fentanyl, Braun, Germany), 1 $\mathrm{mg} / \mathrm{kg}$ propofol (Propofol@) Fresenius containerGermany) and $0.8 \mathrm{mg} / \mathrm{kg}$ rocuronium bromide (curon 50mg/5 $\mathrm{ml}$ iv flk), the patient had orotracheal intubation completed with a no. 7.5 endotracheal tube. With the anesthesia device on volume-control mode (Drager RA 2S-Germany), ventilation was maintained with tidal volume of 6 $\mathrm{mg} / \mathrm{kg}$. Anesthesia maintenance used 50\% air $+50 \%$ oxygen and minimal alveoli cansantration (MAC) 2 concentration of sevoflurane (Sevoflurane, Abbott, USA) and $0.25-0.5 \mathrm{mcg} / \mathrm{kg} / \mathrm{min}$ infusion of remifentanil (Ultiva, Glaxo Smith Kline-Italy). During the procedure HR was 80 and mean arterial pressure was set at $70 \mathrm{mmHg}$. On digital substraction angiography (DSA), left internal carotid artery (ICA) injection showed left MCA M1 segment occlusion (Figure IIA). During the routine progress of the procedure with the sudden development of bradycardia (HR 20 beats/min) and hypertension, $1 \mathrm{mg}$ IV atropine was administered and the neuroradiology team was warned. Contrast material injections demonstrated extravasation due to rupture caused by the navigation of thromboaspiration catheter in the thrombotic segment (Figure IIB). At this point revascularization of the thrombosis segment was cancelled and the procedure was ended. With atropine HR rose above 60 . After the operation lasting nearly 60 minutes, the intubated patient was sent to neurology intensive care unit. Followup CT imaging demonstrated hemorrhage and contrast material in Sylvian fissure (Figure III). Patient was sent to neurology intensive care who died 3. day in neurology intensive care unit.

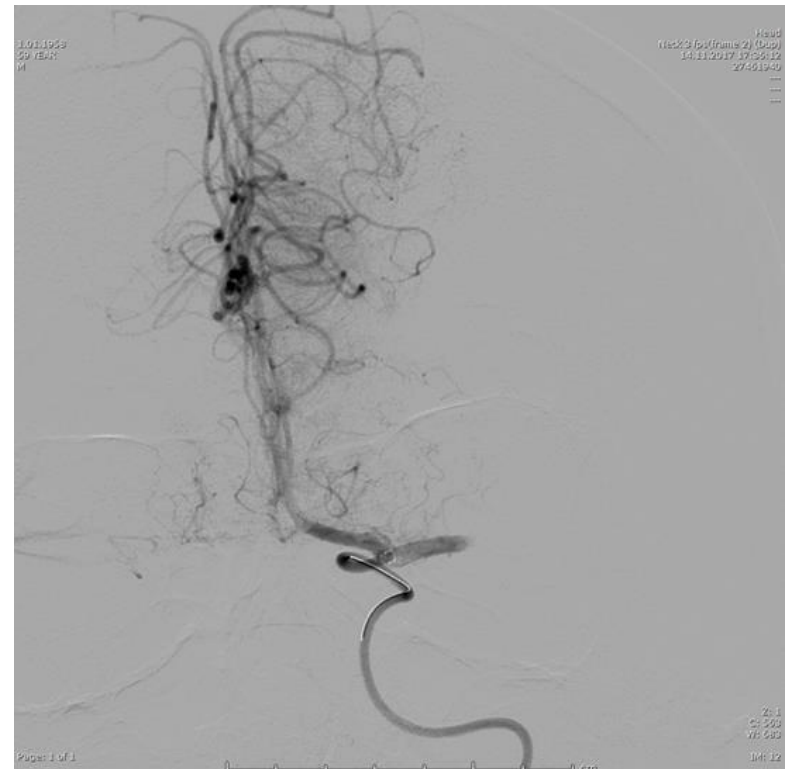

Figure IIA. Left MCA M1 segment occlusion on CT-angiography.

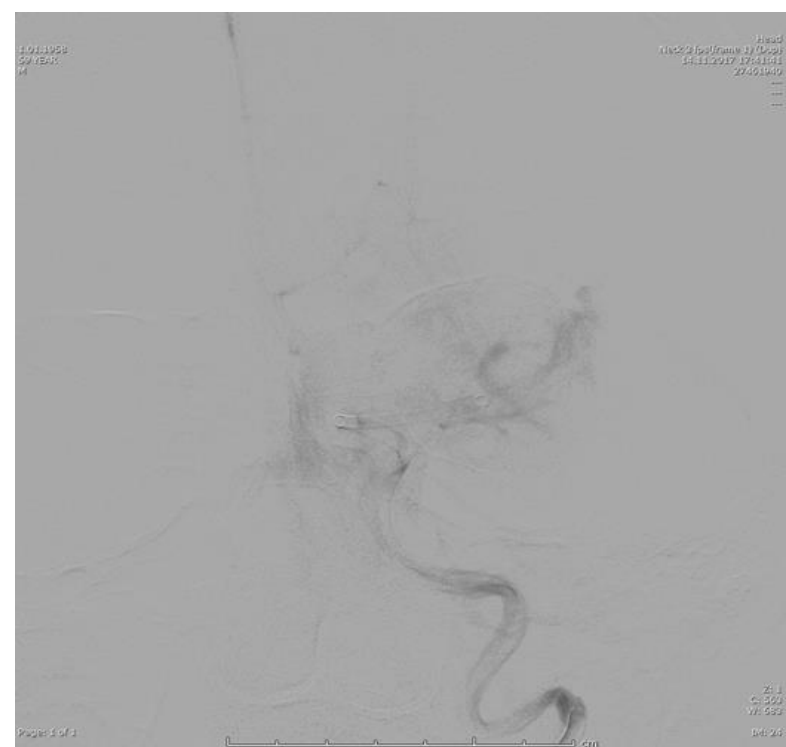

Figure IIB. Extravasation due to rupture caused by the navigation of thromboaspiration catheter in the thrombotic segment on CT-angiography.

\section{DISCUSSION}

Heart rate provides important information about the central nervous system. Tachycardia shows sympathetic discharge. Bradycardia accompanied by high blood pressure may show increased intracranial pressure (ICP) (Cushing reflex) (3). Increased intracranial pressure may be affected by cerebral blood and cerebro spinal fluid (CSF) circulation and many central nervous system

Turkish Journal of Cerebrovascular Diseases 2018; 24 (2): 82-86 


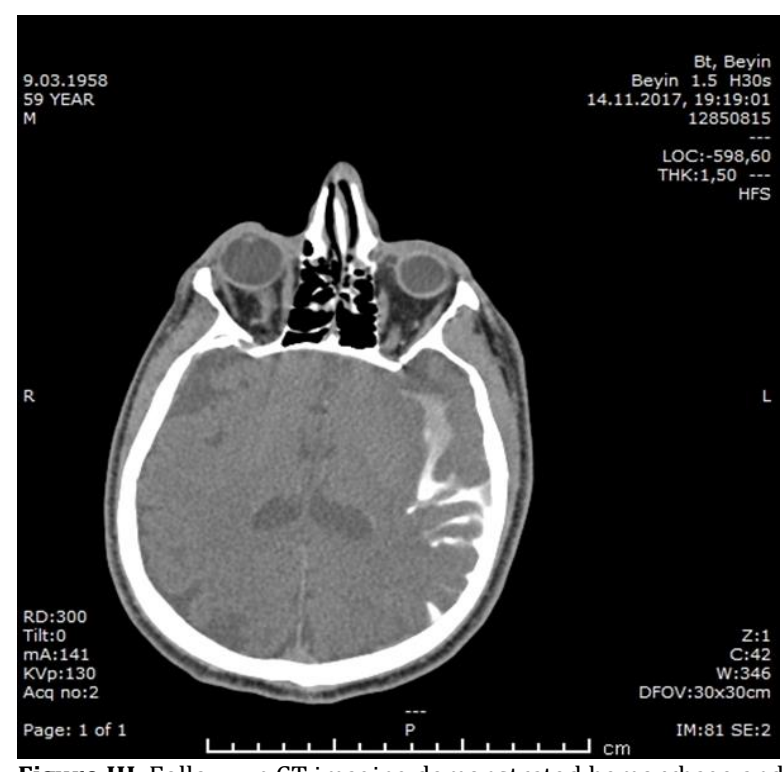

Figure III. Follow-up CT imaging demonstrated hemorrhage and contrast material in Sylvian fissure on Non-contrast computed cerebral tomography (CT).

problems. It is a common life-threatening complication of many neurologic and nonneurologic diseases. It is related to secondary brain damage. If it is undiagnosed and untreated, it may cause mortal results like brain ischemia and brain stem herniation (4). In brain damage, increased ICP is an acute situation, reducing blood perfusion and distribution of oxygen in the brain, causing ischemia and may progress to brain tamponade. Recent studies have shown that early diagnosis and treatment of intracranial hypertension in braindamaged patients is related to better survival (5). Brain edema begins to compress the blood vessels supplying the brain. This compression results in reduced blood flow to the brain and ultimately brain ischemia. The ischemia will then cause the arteries leading to the brain to dilate, causing an additional increase in capillary pressure and a further increase in intracranial pressure. The increased arterial blood pressure caused by the central nerveous system (CNS) ischemic response stimulates the baroreceptors in the carotid bodies, thus slowing the heart rate drastically often to the point of a bradycardia (6). The normal range for ICP varies with age. Values for pediatric subjects are not as well established. Normal values are less than 10 to $15 \mathrm{~mm} \mathrm{Hg}$ for adults and older children, 3 to $7 \mathrm{mmHg}$ for young children, and 1.5 to 6 $\mathrm{mmHg}$ for term infants. ICP values greater than 20 to $25 \mathrm{mmHg}$ require treatment in most circumstances. Sustained ICP values of greater than $40 \mathrm{~mm} \mathrm{Hg}$ indicate severe, life-threatening intracranial hypertension. A decrease in the cerebral perfusion pressure to 15-30 mm Hg often results in a Cushing reflex, but frequently causes hypertension without tachycardia or bradycardia (7). Subarachnoid hemorrhage (SAH), caused in most cases by the rupture of an intracranial aneurysm, is associated with a particularly high mortality of $50 \%$ (1). Most patients die within the first 48 to 72 hours after hemorrhage due to the severity of the initial hemorrhage, rebleedings, and/or the sequelae of early brain injury (1). The mechanisms underlying the early mortality of SAH are not well understood and, hence, therapeutic options are very limited (1). There was a significantly lower mortality rate in the SAH V1 receptor antagonist group (2 of 10 [20\%]) compared with the $\mathrm{SAH}$ _vehicle group (5 of 10 [50\%]) during the 7-day posthemorrhagic observation period $(\mathrm{P}<0.05)(1)$. Hockel K. et al. (1) were doing animal study, demostrated that taken together their results show that AVP V1a receptors mediate systemic hypertension after SAH, thereby exacerbating the initial bleeding, causing rebleedings, and, hence, secondary brain damage, functional deficits, and additional mortality. Our patient was sent to neurology intensive care who died 3. day in neurology intensive care unit. Our patient did not take any V1 receptor antagonist who only taken anti edema treatment. Our patient's artery was ruptured by the navigation of thromboaspiration catheter and happened intracranial haemorrhagia, ICP rise compresses brain vessels and reduces cerebral blood delivery, happened cerabral edema and finally, happened cushing reflex.

In our case, anesthesia maintenance was continuing in a manner that did not disrupt the hemodynamics of the patient under general anesthesia. As the procedure was technically progressing routinely during navigation of the thromboaspiration catheter to the clot localization, with the development of sudden bradycardia and hypertension, the interventional neuroradiology team was warned and $1 \mathrm{mg}$ IV atropine was administered for bradycardia. Simultaneously, contrast material injection through the guide catheter showed rupture of the MCA M1 segment and it was understood extravasation had developed. As conclusion, Cushing reflex is a situation characterized by bradycardia and 
hypertension in cerebrovascular events causing sudden intracranial pressure increases. One of the uncommon complication observed during treatment of cerebrovascular diseases via the endovascular route is intracranial hemorrhage linked to arterial rupture. Prevention of the mortality and morbidity linked to hemorrhagic complications developing during endovascular treatment is based on early awareness and rapid treatment. The anesthesia and team should be on the alert for the Cushing reflex and when variations of hemodynamic parameters in accordance with the Cushing response are observed, informing the operation team immediately has vital importance. Finally, operation team must be alert for vessel perforation when cushing triad develops.

\section{REFERENCES}

1. Leyssens K, Mortelmans T, Menovsky $\mathrm{T}$ et al. The Cushing Reflex: Oliguria as a Reflection of an Elevated Intracranial Pressure. Case Rep Nephrol. 2017; 2017: 2582509.

2. Battistella FD, Benfield JR. Blunt and penetrating injuries of the chest wall, pleura and lungs. In. Shield Tw. General thoracic surgery. 5nd Ed. Philadelphia: Williams and wilkins, 2000: 815-863.

3. Tayal VS, Neulander M, Norton $\mathrm{HJ}$ et al. Emergency department sonographic measurement of optic nerve sheath diameter to detectfindings of increased intracranial pressure in adult head injury patients. Ann Emerg Med. 2007; 49: 508-14.

4. Agrawal A, Timothy J, Cincu $\mathrm{R}$ et al. Bradycardia in neurosurgery. Clin Neurol Neurosurg. 2008; 110: 321-7.

5. Kalmar AF, Van Aken J, Caemaert J et al. Value of Cushing reflex as warning sign for brain ischaemia during neuroendoscopy. Br J Anaesth. 2005; 94: 791-799.

6. Hockel, Scho"ller K, Trabold R, Nussberger J, Plesnila N. Vasopressin V1a Receptors Mediate Posthemorrhagic Systemic Hypertension Thereby Determining Rebleeding Rate and Outcome After Experimental Subarachnoid Hemorrhage. Stroke 2012; 43(1): 227-32.

7. Schmidt EA, Despas F, Pavy-Le Traon A et al. Intracranial Pressure Is a Determinant of Sympathetic Activity. Front Physiol. 2018; 8: 9-11. 